\title{
Determination of measurement uncertainty as a necessary condition confirming the reliability of measurement results
}

\author{
Wyznaczanie niepewności pomiaru jako niezbędny warunek \\ potwierdzający wiarygodność wyników pomiarów
}

\begin{abstract}
The article contains the most important issues related to the measurement uncertainty determination and the presentation of reliable measurement results. It is presented inter alia the most important concepts concerning the measurement uncertainty, the normative requirements, the sources, the purpose and the methods of measurement uncertainty determination. The article also contains a reference to the metrological activities carried out in the Laboratory of Rail Vehicles Tests in order to meet the presented requirements.
\end{abstract}

\begin{abstract}
$W$ artykule zawarto najważniejsze zagadnienia zwiqzane $z$ wyznaczaniem niepewności pomiaru oraz z przedstawianiem wiarygodnych wyników pomiarów. Przedstawiono m.in. najważniejsze pojęcia dotyczqce niepewności pomiaru, wymagania normatywne, źródta, cel oraz metody wyznaczania niepewności pomiaru. Artykuł zawiera również odniesienie do czynności metrologicznych wykonywanych w Laboratorium Badań Pojazdów Szynowych $w$ celu spetnienia przedstawionych wymagań.
\end{abstract}

\section{Introduction}

The Rail Vehicles Research Laboratory operating within the Rail Vehicles Institute of TABOR in Poznań carries out both stationary and moving tests of rail vehicles.

By performing the appropriate, required measurements in accordance with the test program and interpretation of the obtained results, both the durability and safety of the given vehicle are verified. These issues are extremely important in the case of machines which bear a lot of responsibility like rail vehicles. This step is necessary to permit the vehicle type for any kind of travel on the rail lines. It is also extremely important that the required tests are performed in a way that ensures a reliable representation of the conditions occurring during normal vehicle operation.

In addition, in order for the obtained measurement results to be considered reliable, correct, exhaustive and unquestionable, They must be provided along with the expanded uncertainty of a given measurement.

\section{The concept of reliable measurement data}

As mentioned in the introduction, a reliable measurement is a measurement that has been made correctly and which does not raise doubts as to this correctness. The awareness related to the proper presentation of measurement results is constantly increasing nowadays. The measurement uncertainty, which is a parameter related to the measurement result, is a required and extremely important factor to reliably present

\section{Wstęp}

Laboratorium Badań Pojazdów Szynowych działające w ramach Instytutu Pojazdów Szynowych ,TABOR” w Poznaniu przeprowadza zarówno badania stanowiskowe, jak i ruchowe pojazdów szynowych.

Poprzez wykonanie odpowiednich, wymaganych pomiarów zgodnych z programem badań oraz interpretację otrzymanych wyników, weryfikowana jest zarówno trwałość, jak i bezpieczeństwo danego obiektu. Kwestie te są niezwykle ważne w przypadku tak odpowiedzialnych obiektów jak pojazdy szynowe. Bez tego etapu niemożliwe jest dopuszczenie typu pojazdu szynowego do ruchu. Niezwykle istotne jest również, aby wymagane badania przeprowadzane były w sposób zapewniający wiarygodne odwzorowanie warunków występujących podczas normalnej eksploatacji danych pojazdów.

Ponadto, aby wyniki z przeprowadzonych pomiarów uznawane były za wiarygodne, poprawne, wyczerpujące i niebudzące wątpliwości, wymaga się, aby podawać je wraz z niepewnością rozszerzoną danego pomiaru.

\section{Istota wiarygodnych pomiarów}

Jak wspomniano we wstępie, wiarygodny pomiar to pomiar, który wykonano poprawnie i który nie budzi wątpliwości, co do tej poprawności. W obecnych czasach ciagle zwiększa się świadomość związana z odpowiednim przedstawianiem wyników pomiarów. Niepewność pomiaru, będąca parametrem związanym z 
the measurement results. In modern metrology, methods for determining and estimating measurement uncertainty are still being created and improved so that it is beyond doubt.

The measurement uncertainty is therefore extremely important for all measurements performed in laboratories. For this reason, it is recommended that each research laboratory has and applies appropriate procedures for the determination or estimation of measurement uncertainty.

The methods that ensure the reliability of measurements include:

- ensuring consistency through an uninterrupted chain of calibrations and comparisons

- determining and accounting for the measurement uncertainty.

According to the document EA-4/02 M:2013 the result of a given measurement is complete only if it contains both the value of the measured quantity and the uncertainty of measurement related to this value [3].

Measurement consistency (related to measurement unit standards) is a property of a measurement unit or measurement result, showing that they can be linked to reference data using documented calibrations (uninterrupted comparison chain), where all calibration is required to have uncertainties within a given range $[5,12]$.

Preservation of the measurement consistency of the measuring apparatus and instruments used in relation to metrological standards is therefore extremely important in order to ensure the reliability of the measurement results. In order for the testing laboratory to meet this condition, it is necessary to calibrate and supervise any measuring apparatus properly.

According to the PN-EN ISO/IEC 17025:2005 [1] standard, maintaining the consistency is a systemic requirement necessary for a research laboratory in order to obtain accreditation. Meeting this condition is the equivalent of striving to ensure the highest possible precision of measurements. In practice, the measurement consistency is reduced to a formal and documented metrological connection of measuring equipment with given measured value standards [14].

In the Rail Vehicles Research Laboratory, the measurement consistency is ensured by the supervision of measuring equipment, internal and external calibrations, technical checks and inspections.

Calibration consists of a set of operations, carried out in specific conditions. By performing these operations, the relationship between the values of the calibrated object's measured quantity and the standard's indications [13] is determined.

It is also obvious when carrying out measurements that it is necessary to know the appropriate units in which the measured values are given. Knowing the measurement data units is also necessary when com- wynikiem pomiaru, jest czynnikiem wymaganym oraz niezwykle istotnym, aby w wiarygodny sposób przedstawić wyniki pomiarów. We współczesnej metrologii wciąż są tworzone oraz doskonalone metody wyznaczania oraz szacowania niepewności pomiaru w sposób niebudzący wątpliwości.

Niepewność pomiaru jest zatem niezwykle istotna w przypadku wszelkich pomiarów wykonywanych w laboratoriach. $Z$ tego powodu zaleca się, aby każde laboratorium badawcze posiadało oraz stosowało odpowiednie procedury wyznaczania bądź szacowania niepewności pomiaru.

Do sposobów zapewniających wiarygodność pomiarów zalicza się:

- zapewnienie spójności pomiarowej przez nieprzerwany łańcuch wzorcowań i porównań

- wyznaczanie oraz uwzględnianie niepewności pomiaru.

Zgodnie $\mathrm{z}$ dokumentem EA-4/02 M:2013 wynik danego pomiaru jest kompletny tylko, jeżeli zawiera zarówno wartość wielkości mierzonej, jak i niepewność pomiaru związaną z tą wartością [3].

Spójność pomiarowa (powiązanie ze wzorcami jednostki miary) jest to właściwość dotycząca wzorca jednostki miary lub wyniku pomiaru, świadcząca o tym, iż mogą być one powiązane $\mathrm{z}$ danymi odniesieniami za pomocą udokumentowanych wzorcowań (nieprzerwanego łańcucha porównań), przy czym wymaga się, aby wszystkie wzorcowania miały określone niepewności [5, 12].

Zachowanie spójności pomiarowej stosowanej aparatury i przyrządów pomiarowych $\mathrm{w}$ odniesieniu do wzorców metrologicznych jest w związku z tym niezwykle istotne ze względu na zapewnienie wiarygodności wyników pomiarów. Aby laboratorium badawcze spełniło ten warunek, konieczne jest właściwe wzorcowanie oraz nadzorowanie wszelkiej aparatury pomiarowej.

Zgodnie z normą PN-EN ISO/IEC 17025:2005 [1] zachowanie spójności pomiarowej jest wymaganiem systemowym koniecznym do uzyskania akredytacji przez laboratorium badawcze. Spełnienie tego warunku jest tożsame $\mathrm{z}$ dążeniem do zapewnienia możliwie najwyższej precyzji wykonywanych pomiarów. W praktyce zachowanie spójności pomiarowej sprowadza się do formalnego i udokumentowanego powiązania metrologicznego wyposażenia pomiarowego z danymi wzorcami wielkości mierzonych [14].

W Laboratorium Badań Pojazdów Szynowych zachowanie spójności pomiarowej zapewnione jest poprzez nadzorowanie wyposażenia pomiarowego, wykonywanie wzorcowań wewnętrznych i zewnętrznych, sprawdzeń i przeglądów technicznych.

Wzorcowanie (kalibracja) składa się ze zbioru danych operacji, wykonywanych w określonych warunkach. Poprzez zrealizowanie tych operacji określana jest relacja pomiędzy wartościami wielkości mierzonej 
paring test results with one another. For this reason, the International System of Units (SI) is used, which is a coherent, widely recognized and applied metric system. There also exists a global metrological structure, created by appropriate institutions, whose task is to ensure the consistency of measurement data on a global scale. Ensuring this consistency takes place through the proper implementation of a given unit of measure, starting from the definition, through the measurement and calibration standards, to the measuring instrument itself $[9,12]$.

Figure 1 presents the implementation of units of measurement and the chain of consistency in a schematic manner [9].

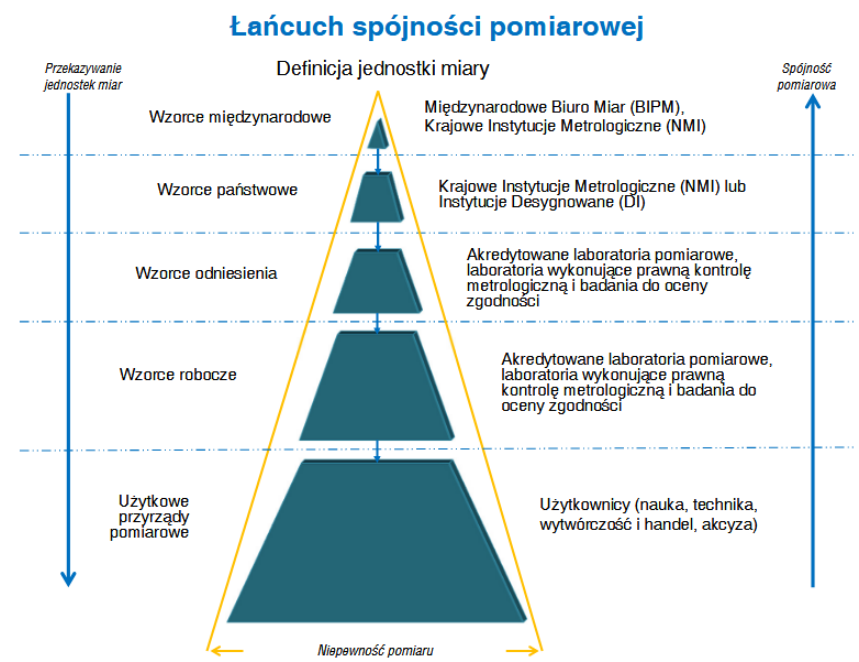

Fig. 1. The chain of measurement consistency [9] Rys. 1. Łańcuch spójności pomiarowej [9]

Legend:

Lańcuch spójności pomiarowej = measurement consistency chain, Przekazywanie jednostek miar = transfer of measurement units, Definicja jednostki miary = measurement unit definition, Spójność pomiarowa $=$ measurement consistency, Wzorce międzynarodowe = international standards, Międzynarodowe Biuro Miar = International Office of Measures, Krajowe Instytucje metrologiczne = National Metrological Institutes, Wzorce państwowe = National standards, Krajowe Instytucje metrologiczne lub Instytucje Desygnowane = National Metrological Institutes or Designated Institutions, Wzorce odniesienia = Reference standards, Akredytowane laboratoria pomiarowe, laboratoria wykonujace prawna kontrole metrologicznq $i$ badania do oceny zgodności $=$ Accredited Measurement Laboratories, laboratories performing the legislated control of metrology and test the measurement consistency, Wzorce robocze = practical standards, Akredytowane laboratoria pomiarowe, laboratoria wykonujace prawna kontrole metrologiczna $i$ badania do oceny zgodności = Accredited Measurement Laboratories, laboratories performing the legislated control of metrology and test the measurement consistency, Uzytkowe przyrzady pomiarowe = functional measuring devices, Użytkownicy (nauka, technika, wytwórczość i handel, akcyza) = Users (scientific, technology, trade and manufacturing, excise), Niepewność pomiaru = measurement uncertainty.

Measurement consistency is characterized by six basic elements [5]:

- an uninterrupted chain of comparisons to an international or national measurement standard

- documented measurement uncertainty

- documented measurement procedure obiektu wzorcowanego a wskazaniami wzorca [13].

Oczywiste jest również przy przeprowadzaniu pomiarów, iż niezbędna jest znajomość odpowiedniej jednostki miary. Znajomość jednostki miary danych pomiarów jest także niezbędna w przypadku porównywania ich wyników ze sobą. $Z$ tego powodu stosuje się Międzynarodowy Układ Jednostek Miar SI, który jest spójnym, powszechnie uznanym i stosowanym systemem metrycznym. Istnieje również światowa struktura metrologiczna, tworzona przez odpowiednie instytucje, których zadaniem jest zapewnienie spójności pomiarowej w skali globalnej. Zapewnienie tej spójności odbywa się poprzez właściwe przekazanie danej jednostki miary od definicji, przez wzorce pomiarowe, aż do przyrządu pomiarowego $[9,12]$.

$\mathrm{Na}$ rysunku 1 przedstawiono w sposób schematyczny przekazywanie jednostek miar [9].

Spójność pomiarowa charakteryzowana jest przez sześć podstawowych elementów [5]:

- nieprzerwany łańcuch porównań do międzynarodowego lub państwowego wzorca pomiarowego

- udokumentowaną niepewność pomiaru

- udokumentowaną procedurę pomiarową

- kompetencje techniczne

- odniesienie do jednostek układu SI, wzorców pomiarowych odniesienia lub procedur pomiarowych zawierających jednostkę miary

- odstępy czasu między wzorcowaniami.

\section{Najważniejsze definicje związane $z$ niepewnością pomiaru}

Mezurand jest to wielkość mierzona, nazywana również wielkością wyjściową $\boldsymbol{Y}$ zależną od wielkości wejściowych $\boldsymbol{X}_{\mathbf{i}}(\mathrm{i}=1,2, \ldots, \mathrm{n})$ zgodnie $\mathrm{z}$ zależnością (3):

$$
Y=f\left(X_{1}, X_{2}, \ldots, X_{\mathrm{n}}\right)
$$

Funkcja $f$ nazywana jest funkcją pomiaru. Funkcja ta opisuje zarówno procedure pomiarową, jak i metodę obliczeniowa. Funkcja pomiaru określa, w jaki sposób z wartości wielkości wejściowych $X_{\mathrm{i}}$ otrzymuje się wartość wielkości wyjściowej $Y$.

Funkcja ta może być pojedynczym wyrażeniem analitycznym bądź zbiorem wyrażeń analitycznych, które zawierają poprawki oraz współczynniki poprawkowe oddziaływań systematycznych. Funkcja pomiaru $f$ może zostać określona eksperymentalnie lub poprzez algorytm komputerowy wyznaczany numerycznie, a może również być kombinacją wymienionych form [3].

Zgodnie z definicją Międzynarodowego Słownika Podstawowych i Ogólnych Terminów Metrologii wydanego przez ISO niepewność pomiaru jest to parametr związany z wynikiem pomiaru, charakteryzujący rozrzut wartości, które można w uzasadniony sposób 
- technical competence

- reference to SI units system or to measurement standards or measurement procedures containing a unit of measurement

- intervals between calibrations.

3. The most important definitions related to measurement uncertainty

Measurand is the measured quantity, also known as the output value $\boldsymbol{Y}$ resulting from the input values $\boldsymbol{X}_{\mathbf{i}}(\mathrm{i}=1,2, \ldots, \mathrm{n})$ in accordance with (3):

$$
Y=f\left(X_{1}, X_{2}, \ldots, X_{\mathrm{n}}\right) .
$$

The function $f$ is called the measurement function. This function describes both the measurement procedure and the calculation method. The measurement function determines how the output value $Y$ is obtained from the input values $X_{\mathrm{i}}$.

This function can be a single analytical expression or a set of analytical expressions that contain corrections and correction factors for systematic interactions. The measurement function $f$ can be determined experimentally or by a computer algorithm determined numerically, it can also be a combination of these two methods [3].

According to the definition of the International Dictionary of Basic and General Metrology Terms issued by ISO, measurement uncertainty is a parameter related to the measurement result, characterizing the spread of values that can be reasonably attributed to the measured value. Such a parameter can be a standard deviation or other part of the range indicating the specified confidence level [3, 7].

The standard measurement uncertainty $u(y)$, which is related to the estimate of the initial value (measurement result) is (usually) the standard deviation of the $Y$ measurand [3].

The complex standard uncertainty of measurement is determined on the basis of the estimates $x_{\mathrm{i}}$ $(\mathrm{i}=1,2, \ldots, \mathrm{n})$ of the input values $X_{\mathrm{i}}$ and on the basis of the standard uncertainties associated with them $u\left(x_{\mathrm{i}}\right)$, it should be noted that the unit of a standard uncertainty associated with the given estimate is identical to the unit of this estimate. The complex standard uncertainty of measurement is equal to the square root of the sum of expressions, being the variances of the input values with weights depending on how the measurement result varies with the changes of these quantities $[3,8]$.

Expanded uncertainty $\boldsymbol{U}$ is the value that determines the range around the measurement result, which is assumed to cover a significant part of the distribution of values assigned to the measured value in a justified way. The expanded uncertainty is obtained by multiplying the complex standard uncertainty and the expansion coefficient $k$ [8]. przypisać wielkości mierzonej. Takim parametrem może być odchylenie standardowe lub inna część przedziału wskazującego określony poziom ufności $[3,7]$.

Standardowa niepewność pomiaru $\boldsymbol{u}(\boldsymbol{y})$, która jest związana z estymatą wielkości wyjściowej (wynikiem pomiaru) jest (zazwyczaj) odchyleniem standardowym mezurandu $Y[3]$.

Zlożoną standardową niepewność pomiaru wyznacza się na podstawie estymat $x_{\mathrm{i}}(\mathrm{i}=1,2, \ldots, \mathrm{n})$ wielkości wejściowych $X_{\mathrm{i}}$ oraz na podstawie związanych z nimi niepewności standardowych $u\left(x_{\mathrm{i}}\right)$, przy czym należy zaznaczyć, iż niepewność standardowa związana $z$ daną estymatą ma wymiar identyczny $\mathrm{z}$ wymiarem tej estymaty. Złożona standardowa niepewność pomiaru równa jest pierwiastkowi sumy wyrażen, będących wariancjami wielkości wejściowych $\mathrm{z}$ wagami zależnymi od tego, jak wynik pomiaru zmienia się wraz ze zmianami tych wielkości $[3,8]$.

Niepewność rozszerzona $\boldsymbol{U}$ jest to wielkość, która określa przedział wokół wyniku pomiaru, wobec którego zakłada się, iż obejmuje znaczną część rozkładu wartości w uzasadniony sposób przypisanych wielkości mierzonej. Niepewność rozszerzoną uzyskuje się poprzez iloczyn złożonej niepewności standardowej i współczynnika rozszerzenia $k$ [8].

\section{Cel wyznaczania niepewności pomiaru oraz wy- magania normatywne}

Wyznaczanie oraz podawanie niepewności pomiaru wraz z wartością wielkości mierzonej jest jednym z wymagań stawianych akredytowanym laboratoriom badawczym. Przewodnik GUM [2] wymaga, aby stosować model wyznaczania niepewności, który obejmuje wszystkie składowe znacząco wpływające na niepewność wyniku badań.

Dodatkowo klienci akredytowanych laboratoriów badawczych, poprzez swoje oczekiwania, narzucaja konieczność przedstawiania sprawozdań z badań $\mathrm{W}$ sposób niebudzący wątpliwości, iż zostały one przeprowadzone poprawnie, a wyniki są użyteczne, powtarzalne oraz wyczerpujące. Klienci mogą również oczekiwać przedstawienia właściwości jakościowych, między innymi wiarygodności wyników oraz ilościowego określania tej wiarygodności, na przykład poprzez podanie niepewności, czy też określenia poziomu zaufania do oświadczenia o zgodności danego wyrobu.

Należy podkreślić, iż wyznaczona niepewność pomiaru w żadnym wypadku nie jest wada, opisuje natomiast rzeczywistą jakość oraz pewność danych pomiarów. Należy zatem unikać mylenia niepewności pomiaru z błędem pomiarowym. Niepewność pomiaru jest niezbędną informacją wymaganą, by wyrazić całkowity wynik pomiaru [6].

Zgodnie z dokumentem ILAC-G17:2002 - Wprowadzenie problematyki niepewności pomiaru w badaniach $\mathrm{w}$ związku z wejściem do stosowania normy ISO/IEC 17025 [6]: 


\section{The purpose of measurement uncertainty deter- mination and normative requirements}

The determination and notation of measurement uncertainty along with the value of the measured quantity is one of the requirements for accredited testing laboratories. The GUM guide [2] requires that the uncertainty model be applied, which includes all components that significantly affect the uncertainty of the test result.

In addition, the clients of accredited research laboratories, through their expectations, impose the necessity of presenting research reports in a way that leaves little doubt that they have been carried out correctly and that the results are useful, repeatable and consistent. Clients may also expect the presentation of qualitative characteristics, including the reliability of the results and the quantification of this reliability, for example by specifying the uncertainty or determining the level of confidence in the statement of conformity of a given product.

It should be emphasized that the determined measurement uncertainty is in no way a disadvantage, but describes the actual quality and reliability of the measurements. It is therefore necessary to avoid confusing the measurement uncertainty with a measurement error. The uncertainty of measurement is the necessary information required to express the total measurement result [6].

According to the ILAC-G17:2002 document - Introduction of measurement uncertainty in research in connection with the entry of ISO/IEC 17025 [6] into effect:

- the basic documents are the GUM Guide [2] and the ISO/IEC 17025 norm [1]

- uncertainty of measurement is taken into account only in quantitative research, i.e. in studies in which numerical values for a given aspect or measured quantity are obtained

- a recommendation exists that the main requirement should be to assess the overall uncertainty or to identify its main components along with an estimate of their value and the magnitude of the combined uncertainty

- three variants for using standard methods can be distinguished, namely:

- a laboratory that uses the standard method in which uncertainty estimation guidelines have been provided must only follow the procedure for estimating the uncertainty of the standard method. In this case, the laboratory must demonstrate full compliance with the test methods

○ if the laboratory shows full compliance with the test method, then the uncertainty of measurement can be calculated according to the typical measurement uncertainty for the test results as given in the norm
- podstawowymi dokumentami są Przewodnik GUM [2] oraz norma ISO/IEC 17025 [1]

- niepewność pomiaru jest brana pod uwage jedynie w badaniach ilościowych, czyli w badaniach, w których otrzymywane są wartości liczbowe dla danej cechy lub wielkości mierzonej

- istnieje zalecenie, by głównym wymaganiem było oszacowanie niepewności całkowitej lub zidentyfikowanie głównych składników wraz z oszacowaniem ich wielkości i wielkości niepewności złożonej

- można wyróżnić trzy warianty w przypadku stosowania metod standardowych, mianowicie:

- laboratorium, które stosuje metodę standardową, w której podane zostały wytyczne dotyczące szacowania niepewności, musi jedynie postępować według procedury szacowania niepewności metody standardowej. W tym przypadku laboratorium musi wykazać pełną zgodność z metodami badawczymi

- jeżeli laboratorium wykazuje pełną zgodność z metodą badawczą, wówczas pozwala się obliczać wartość niepewności pomiaru według podanej $\mathrm{w}$ normie typowej niepewności pomiarowej dla wyników badań

○ jeżeli laboratorium wykazuje pełną zgodność z metodą badawczą, a norma podaje niepewność pomiaru rezultatów badania, wówczas nie wymaga się dalszych działań ze strony laboratorium

- w przypadku, gdy oszacowanie niepewności jest ograniczone, musi być to podane w każdym sprawozdaniu dotyczącym niepewności.

Przewodnik GUM wyszczególnia podstawowe koncepcje w wyznaczaniu niepewności [2, 4]:

- wielkości mające wpływ na wielkość mierzoną $\mathrm{z}$ założenia nie są $\mathrm{w}$ pełni znane, stąd mogą być wyrażone za pomocą funkcji gęstości prawdopodobieństwa (PDF - Probability Density Function) wartości, które można przypisać danemu parametrowi

- oczekiwana wartość PDF jest określona za pomocą najlepszego przybliżenia wartości danej wielkości

- odchylenie standardowe PDF jest określone za pomocą niepewności standardowej powiązanej $\mathrm{z}$ tym oszacowaniem

- PDF określona jest na podstawie wiedzy o wielkości, zdobytej na podstawie:

○ powtarzalnych wyników - wyznaczenie typu A

- ocenie naukowej mającej podstawę we wszystkich dostępnych informacjach o możliwościach wpływu na zmienność danej wielkości wyznaczenie typu B. 
o if the laboratory is in full compliance with the test method and the norm provides uncertainty for the test measurements, then no further action from the laboratory is required

- in the event that the uncertainty estimate is limited, it must be included in each uncertainty report.

The GUM guide specifies the basic concepts in determining uncertainty $[2,4]$ :

- the magnitudes affecting the measured quantity are, by definition, not fully known. Hence, they can be expressed using the value Probability Density Function (PDF) that can be assigned to a given parameter

- The expected PDF value is determined by the best approximation of the given parameter's value

- The standard deviation of PDF is determined by the standard uncertainty associated with this estimate

- PDF is defined based on the knowledge of the parameter or variable, obtained using:

- repeatable results - type A determination method

○ the scientific assessment that encompasses all available information on the possible aspects that can affect the value of a given variable - type B determination method.

As outlined in PN-EN ISO/IEC 17025:2005 General competence requirements for the research and calibration laboratories [1]:

- the laboratory should have calibration instructions. All instructions relevant to the laboratory's work should be frequently updated and easily accessible to staff

- both a calibration laboratory and a research laboratory, which carries out its own calibrations, should possess and utilize a procedure for estimating the measurement uncertainty for all calibration types

- in some cases, the nature of the test method may prevent strict, metrologically and statistically justified calculations of measurement uncertainty. In such cases, the laboratory should try to identify all uncertainty components, rationally estimate them, and ensure that the presentation of results does not give a false impression of uncertainty

- the accuracy of measurement uncertainty estimation depends on the requirements included in the research method, client's requirements, a narrow range of limits being the basis on which a decision on compliance with the specification to be made
Zgodnie z normą PN-EN ISO/IEC 17025:2005 Ogólne wymagania dotyczące kompetencji laboratoriów badawczych i wzorcujących [1]:

- laboratorium powinno posiadać instrukcje wzorcowania. Wszystkie instrukcje istotne dla pracy laboratorium powinny być stale aktualizowane i łatwo dostępne dla personelu

- zarówno laboratorium wzorcujące, jak i laboratorium badawcze, które przeprowadza własne wzorcowania, powinno posiadać oraz stosować procedurę szacowania niepewności pomiaru dla wszystkich typów wzorcowań

- w pewnych przypadkach charakter metody badawczej może uniemożliwić ścisłe, metrologicznie i statystycznie uzasadnione, obliczenie niepewności pomiaru. W takich przypadkach laboratorium powinno spróbować zidentyfikować wszystkie składniki niepewności i racjonalnie je oszacować oraz zapewnić, że sposób przedstawiania wyników nie daje błędnego wrażenia odnośnie niepewności

- ścisłość szacowania niepewności pomiaru zależy od wymagań zawartych w metodzie badawczej, wymagań klienta, wąskiego zakresu granic będących podstawą do podjęcia decyzji o zgodności ze specyfikacją

- przy szacowaniu niepewności pomiaru należy wziąć pod uwagę wszystkie składniki niepewności, które są istotne w danej sytuacji, z wykorzystaniem odpowiednich metod analizy

- w laboratoriach wzorcujących program dotyczący wzorcowania wyposażenia powinien być opracowany i realizowany w taki sposób, aby zagwarantować, iż wzorcowania i pomiary wykonywane przez laboratorium są powiązane z Międzynarodowym Układem Miar SI. Laboratorium wzorcujące ustala powiązanie swoich własnych wzorców jednostek miar i przyrządów pomiarowych $\mathrm{z}$ jednostkami SI za pośrednictwem nieprzerwanego łańcucha wzorcowań lub porównań łączących je z odpowiednimi wzorcami jednostek miar SI

- w przypadku korzystania z zewnętrznych usług w zakresie wzorcowania, spójność pomiarową powinno zapewnić korzystanie z usług laboratoriów, które mogą wykazać kompetencje, możliwość pomiarowa i powiązanie $\mathrm{z}$ wzorcami jednostek miar. Świadectwa wzorcowań, wydawane przez te laboratoria powinny zawierać wyniki pomiarów wraz $\mathrm{z}$ niepewnością pomiaru.

Istnieje również wiele korzyści z wyznaczania niepewności pomiaru przez laboratoria, $\mathrm{m}$. in. [8]:

- znajomość wartości niepewności danego pomiaru może okazać się użyteczna w rozwiązaniu istotnych problemów związanych na przykład ze sterowaniem ryzykiem lub oceną wia- 
- all uncertainty components relevant in a given situation should be taken into account, using appropriate analysis methods, when estimating the uncertainty of a measurement

- in calibration laboratories, the equipment calibration plan should be developed and implemented in such a way as to ensure that the calibration and measurements performed by the laboratory are related to the International System of Measurements SI. Calibration laboratory establishes the connection of its own measurement units and measurement instrument sets with SI units via a continuous chain of calibrations or comparisons connecting them with the appropriate SI measurement units

- when using external calibration services, measurement consistency should be ensured using laboratory services that can demonstrate competence, measurement capability and linking to the measurement unit standards. Calibration certificates issued by these laboratories should contain measurement results and the measurement uncertainty.

There are also many benefits from determining uncertainty of measurement by laboratories, such as [8]:

- knowing the uncertainty of a given measurement may be useful in solving significant problems related to, for example, risk control or credibility assessment of measurement results

- providing the measurement uncertainty along with the value of the measured variable increases the value of the collected data by increasing the reliability and consistency of the result

- the reliability of the entire research method is also increased by the knowledge of the quantitative impact of individual variables on the final result of the study, additionally thanks to this knowledge it is possible to introduce and improve more effective corrective actions, and thus to reduce the research costs

- the established measurement uncertainty can be the starting point for optimizing research procedures thanks to a better understanding of the research process

- the requirements of customers, especially certification bodies, are fully satisfied.

\section{Sources of measurement uncertainty}

The measurement result uncertainty is related to the lack of full knowledge of the value of the measured quantity. To acquire this full knowledge of the measured quantity would require a large amount of information, which in practice is impossible to obtain. In order to analyze the most important sources of uncertainty in rygodności wyników pomiaru

- podanie wartości niepewności pomiaru wraz z wartością wielkości mierzonej zwiększa konkurencyjność pomiaru poprzez zwiększenie wiarygodności i zrozumiałości wyniku

- zwiększona jest również wiarygodność całej metody badawczej dzięki znajomości ilościowych wpływów pojedynczych wielkości na końcowy wynik badania, dodatkowo dzięki tej wiedzy możliwe jest wprowadzanie i doskonalenie skuteczniejszych działań korygujących, a więc i zmniejszenie kosztów

- wyznaczona niepewność pomiaru może stanowić punkt wyjściowy do optymalizacji procedur badawczych dzięki lepszemu zrozumieniu procesu badawczego

- wymagania klientów, zwłaszcza jednostek certyfikujących, zostają w pełni zaspokojone.

\section{5. Źródła niepewności pomiaru}

Niepewność wyniku pomiaru związana jest z brakiem pełnej znajomości wartości wielkości mierzonej. Pełna znajomość wartości wielkości mierzonej wymagałaby dużej liczby informacji, co w praktyce jest niemożliwe do uzyskania. Chcąc przeanalizować najważniejsze źródła niepewności danego pomiaru należy zatem skupić się na wyznaczonym budżecie niepewności. Na budżet niepewności składają się wszystkie wyniki oszacowań lub obliczeń statystycznych składników niepewności, które wpływają na niepewność wyniku pomiaru. Słowo budżet odnosi się do przypisania wartości liczbowych do danych składników niepewności, czyli inaczej mówiąc budżet niepewności jest to analiza niepewności pomiaru. Natomiast sposób pomiaru oraz warunki pomiaru decydują o złożeniu oraz rozszerzeniu tych składników niepewności $[3,12]$.

Dla najistotniejszych czynników wpływających na niepewność pomiaru należy wyznaczyć niepewności standardowe. Do najistotniejszych czynników zaliczyć można wzorce i materiały odniesienia, zastosowane metody oraz wyposażenie, warunki środowiskowe, właściwości i stan obiektów poddawanych badaniu lub wzorcowaniu oraz wykonujący badanie lub wzorcowanie [8].

Warto przy tym podkreślić, że nie należy dążyć do uwzględniania wszystkich czynników, natomiast powinno się skupić na czynnikach mających istotny wkład do budżetu niepewności. W praktyce jedynie niektóre ze źródeł znacząco wpływają na niepewność pomiaru. Zatem dobre oszacowania niepewności można otrzymać minimalnym kosztem, skupiając się na najistotniejszych źródłach.

Dokument EA-4/02 M:2013 [3] do możliwych źródeł niepewności pomiaru zalicza:

- niepełną definicję wielkości mierzonej

- niedoskonałą realizację definicji wielkości mierzonej 
a given measurement, one should focus on the uncertainty budget. The uncertainty budget consists of all the results of estimates or statistical calculations of uncertainty components that affect the measurement result uncertainty. The word budget refers to the assignment of numerical values to given uncertainty components, in other words the uncertainty budget is the analysis of measurement uncertainty. However, the measurement method and measurement conditions determine the composition and extension of these uncertainty components [3, 12].

Standard uncertainties should be determined for the most important factors affecting the measurement uncertainty. The most important factors include reference standards and materials, applied methods and equipment, environmental conditions, properties and condition of objects undergoing testing or calibration, and the persons performing tests or calibrations [8].

It is worth emphasizing that one should not strive to take into account all the factors, but rather focus on factors having a significant contribution to the uncertainty budget. In practice, only some of the sources significantly affect the measurement uncertainty. Therefore, good estimates of uncertainty can be obtained at a minimum cost, focusing on the most important sources.

Document EA-4/02 M:2013 [3] lists the following possible sources of measurement uncertainty:

- incomplete definition of the measurand

- imperfect measurand definition implementation

- incorrect (unrepresentative) sampling

- incomplete knowledge of the impact that environmental conditions have on the measurement procedure

- incorrect measurement of parameters characterizing the environmental conditions

- read errors from analog devices

- limited measurement resolution

- inaccurate values assigned to reference standards and materials

- inaccurate values of constants and other parameters derived from external sources

- use of approximations and simplified assumptions in measurement methods and procedures

- the dispersion of the measured variable values obtained from tests repeated under apparently identical conditions.

It should be noted that these sources are not always independent.

[8]:

These sources of uncertainty are not included

- unidentified systematic errors

- random errors.
- niewłaściwe (niereprezentatywne) pobranie próbki

- niepełną znajomość wpływu warunków środowiskowych na procedurę pomiarową

- nieprawidłowy pomiar parametrów charakteryzujących warunki środowiskowe

- błędy odczytu, w przypadku korzystania z przyrządów analogowych

- ograniczoną rozdzielczość odczytu

- niedokładną znajomość wartości przypisanych wzorcom i materiałom odniesienia

- niedokładną znajomość wartości stałych i innych parametrów pochodzących ze źródeł zewnętrznych

- stosowanie przybliżeń oraz uproszczonych założeń w metodach i procedurach pomiarowych

- rozrzut wartości wielkości mierzonej otrzymanych podczas obserwacji powtarzanych w warunkach pozornie identycznych.

Należy zaznaczyć, iż źródła te nie zawsze są niezależne.

Do źródeł niepewności nie są zaliczane [8]:

- nierozpoznane błędy systematyczne

- błędy grube.

\section{Metody oraz etapy wyznaczania niepewności pomiaru}

Wyróżnia się dwie podstawowe metody wyznaczania niepewności standardowej $u\left(x_{\mathrm{i}}\right)$ [8]:

- metoda A - niepewność standardowa wyznaczana na podstawie analizy statystycznej serii pojedynczych pomiarów

- metoda B - niepewność standardowa wyznaczana na podstawia posiadanych informacji.

Możliwe jest zatem podzielenie zbioru wielkości wejściowych na dwie kategorie. Do kategorii pierwszej zalicza się wielkości, których estymaty oraz niepewności wyznacza się bezpośrednio z pomiaru, zarówno $\mathrm{z}$ pojedynczej obserwacji, jak i z wielu powtarzanych obserwacji. Wartości te zawierać mogą wyznaczanie poprawek wskazań przyrządu, jak i poprawek związanych $\mathrm{z}$ wielkościami wpływającymi, np. $\mathrm{z}$ temperaturą otoczenia, ciśnieniem atmosferycznym, czy wilgotnością.

W kategorii drugiej wyróżnia się wielkości, których estymaty oraz niepewności wyznaczane są na podstawie źródeł zewnętrznych. Są to np. wielkości związane $\mathrm{z}$ wywzorcowanymi wzorcami pomiarowymi, certyfikowanymi materiałami odniesienia, czy też danymi odniesienia pochodzącymi z literatury specjalistycznej [3].

Należy zaznaczyć, iż właściwie uzasadnione wyznaczanie niepewności standardowej metodą typu B jest tak samo wiarygodne, jak jej wyznaczanie metodą typu A, zwłaszcza, gdy wyznaczanie niepewności pomiaru typu A miałoby się opierać na stosunkowo małej liczbie statystycznie niezależnych obserwacji [3]. 


\section{Methods and stages of determining measurement uncertainty}

There are two basic methods for determining standard uncertainty $u\left(x_{\mathrm{i}}\right)[8]$ :

- method A - standard uncertainty determined based on statistical analysis of a series of individual measurements

- method B - standard uncertainty determined based on available information.

It is therefore possible to divide the set of input quantities into two categories. The first category includes the values whose estimates and uncertainties are determined directly from the measurement, both from a single observation and from many repeated observations. These values can include corrections determined for the instrument's indications, as well as corrections related to the parameters influencing the result, e.g. ambient temperature, atmospheric pressure or humidity.

The second category includes values whose estimates and uncertainties are determined based on external sources. These are, for example, quantities related to calibrated measurement standards, certified reference materials, or reference data from specialist literature [3].

It should be noted that properly justified determination of standard uncertainty using the B-type method is just as reliable as its determination using the Amethod, especially when determining the uncertainty of type A measurement would be based on a relatively small number of statistically independent observations [3].

To estimate the measurement uncertainty, these guidelines should be followed:

- specify the quantity measured and the unit

- provide a mathematical model of measurement (or a measurement equation), i.e. identify input factors (influencing factors)

- based on the measurement model, the measurement uncertainty equation should be determined, i.e. an analysis of measurement uncertainty sources should be performed

- then, determine the sensitivity coefficients and present the budget for measurement uncertainty

- calculate the complex standard uncertainty of measurement (from the uncertainty propagation equation) and the expanded uncertainty of the measurement.

The presented guidelines for estimating measurement uncertainty are based on assumptions resulting from reference documents [2, 3].

Standard uncertainties of relevant factors are determined through a mathematical measurement model. The individual uncertainty contributing values are quantified in accordance with the principle of propagating the measurement uncertainty (Gaussian method) by calculating the sensitivity coefficients. In accor-
W celu oszacowania niepewności pomiaru należy postępować zgodnie z następującymi wskazówkami:

- należy określić wielkość mierzoną wraz z jednostką

- należy podać matematyczny model pomiaru (inaczej równanie pomiaru), czyli zidentyfikować czynniki wejściowe (czynniki wpływające)

- na podstawie modelu pomiaru należy wyznaczyć równanie niepewności pomiaru, czyli przeprowadzić analizę źródeł niepewności pomiaru

- następnie należy wyznaczyć współczynniki wrażliwości oraz przedstawić budżet niepewności pomiaru

- obliczyć złożoną standardową niepewność pomiaru (z równania propagacji niepewności) oraz niepewność rozszerzoną pomiaru.

Przedstawione wskazówki odnośnie szacowania niepewności pomiaru opierają się na założeniach wynikających z dokumentów odniesienia $[2,3]$.

Niepewności standardowe istotnych czynników określone zostają poprzez matematyczny model pomiaru. Poszczególne udziały niepewności są zwartościowane $\mathrm{w}$ sposób ilościowy zgodnie $\mathrm{z}$ zasada propagacji niepewności pomiaru (metoda Gaussa) poprzez wyliczenie współczynników wrażliwości. Zgodnie z ogólnie przyjętą zasadą, dany współczynnik wrażliwości równy jest pochodnej cząstkowej równania modelu.

Należy również wziąć po uwagę, iż czynniki określające złożone techniczne interakcje, których przedstawienie bezpośrednio w modelu matematycznym byłoby problematyczne (np. zużycie, zanieczyszczenie, tolerancja wykonania, odchyłki kształtu, drgania itp.), zostają zawarte w pomiarach jako wynik sumaryczny [10].

\section{Wiarygodność pomiarów wykonywanych w La- boratorium Badań Pojazdów Szynowych}

W Laboratorium Badań Pojazdów Szynowych wykonuje się szereg czynności metrologicznych mających na celu zapewnienie spójności pomiarowej. Wykonywane są wzorcowania wewnętrzne, wzorcowania zewnętrzne, sprawdzenia oraz przeglądy techniczne. Czynności te są wykonywane w Pracowni PomiarowoTechnicznej Laboratorium zgodnie $\mathrm{z}$ odpowiednimi Procedurami Metrologicznymi PM-01 $\div 07 \mathrm{w}$ terminach zawartych w harmonogramach. Procedury Metrologiczne PM-01 $\div 07$ dotyczą wzorcowania następujących przyrządów pomiarowych [11]:

- mierników elektrycznych - Procedura Metrologiczna PM-01

- mierników ciśnienia - Procedura Metrologiczna PM-02

- mierników temperatury - Procedura Metrologiczna PM-03 
dance with the generally accepted principle, any given sensitivity factor is equal to the partial derivative of the model equation.

It should also be taken into account that the factors determining complex technical interactions, which would be problematic in the mathematical model (such as: consumption, contamination, manufacturing tolerances, shape deviations, vibrations, etc.), are included in the measurements as a part of the total sum [10].

\section{Credibility of measurements performed in the Rail Vehicles Research Laboratory}

A number of metrological activities are carried out in the Rail Vehicles Research Laboratory to ensure measurement consistency. Internal calibrations, external calibrations, checks and technical inspections are performed. These activities are carried out in the Measurement and Technical Laboratory in accordance with the relevant Metrological Procedures PM-01 $\div 07$ in accordance with the terms included in the schedules. The Metrological Procedures PM- $01 \div 07$ concern the calibration of the following measuring instruments [11]:

- electric meters - Metrological Procedure PM-01

- pressure meters - Metrological Procedure PM-02

- temperature meters - Metrological Procedure PM-03

- devices for measuring lengths and angles - Metrological Procedure PM-04

- time measurement equipment - Metrological Procedure PM-05

- devices for measuring the path and determining the wheel diameter of a rail vehicle - Metrological Procedure PM-06

- dynamometers - Metrological Procedure PM-07.

In addition, the Metrological Procedures PM-01 07 contain methods for determining the uncertainty of calibration results and algorithms for calculating the calibration uncertainty of given measuring instruments.

In a situation where a given device cannot be calibrated in the Laboratory, it is sent for external calibration to an accredited unit in PCA. The unit is selected using the register of qualified service providers, which is regularly maintained by the Measurement and Technical Laboratory at the Facility.

The Metrological Procedures PM-01 $\div 07$ therefore provide measurement consistency by linking their own standards and measuring apparatus with the help of an uninterrupted calibration chain with the appropriate national standards [11].

Therefore, it should be emphasized that the Rail Vehicles Research Laboratory meets the normative requirements specified in this article, ensures the measurement consistency and determines the measurement uncertainty for obtained measurement results, thus ensuring the results reliability of the performed measurements.
- przyrządów do pomiaru długości i kąta - Procedura Metrologiczna PM-04

- aparatury do pomiaru czasu - Procedura Metrologiczna PM-05

- mierników do pomiaru drogi i wyznaczania średnicy koła pojazdu szynowego - Procedura Metrologiczna PM-06

- siłomierzy - Procedura Metrologiczna PM-07.

Ponadto Procedury Metrologiczne PM-01 $\div 07$ zawierają sposoby opracowywania niepewności wyników wzorcowania danych przyrządów pomiarowych oraz algorytmy postępowania przy obliczaniu niepewności wzorcowania danych przyrządów pomiarowych.

W sytuacji, gdy dany przyrząd nie może być wywzorcowany w Laboratorium, wysyłany jest w celu wykonania wzorcowania zewnętrznego do jednostki akredytowanej w PCA. Jednostka taka wybierana jest na podstawie rejestru kwalifikowanych dostawców usług, który jest na bieżąco prowadzony przez Pracownię Pomiarowo-Techniczną w Laboratorium.

Procedury Metrologiczne PM-01 $\div-07$ zapewniaja zatem spójność pomiarową poprzez powiązanie własnych wzorców oraz aparatury pomiarowej za pomocą nieprzerwanego łańcucha wzorcowań z odpowiednimi wzorcami państwowymi [11].

Podkreślić zatem należy, iż Laboratorium Badań Pojazdów Szynowych spełnia wymagania normatywne wyszczególnione $\mathrm{w}$ niniejszym artykule, zapewnia zachowanie spójności pomiarowej oraz wyznacza niepewności pomiaru dla przeprowadzanych pomiarów zapewniając tym samym wiarygodność otrzymywanych wyników przeprowadzanych pomiarów.

\section{Podsumowanie}

W niniejszym artykule przedstawiono najważniejsze zagadnienia związane $\mathrm{z}$ niepewnością pomiaru $\mathrm{w}$ kontekście zapewnienia wiarygodności wykonywanych pomiarów. Scharakteryzowano cechy wiarygodnego pomiaru oraz zawarto najistotniejsze definicje związane z niepewnością pomiaru. Wymieniono również cele, metody i etapy wyznaczania oraz źródła niepewności pomiaru. Podkreślono, iż Laboratorium Badań Pojazdów Szynowych działające w ramach Instytutu Pojazdów Szynowych TABOR w Poznaniu zapewnia wiarygodność wykonywanych pomiarów poprzez stosowanie się do wymagań normatywnych, tzn. zachowanie spójności pomiarowej oraz wyznaczanie niepewności pomiaru.

\section{Bibliography / Bibliografia}

[1] PN-EN ISO/IEC 17025:2005. Ogólne wymagania dotyczqce kompetencji laboratoriów badawczych $i$ wzorcujacych.

[2] Przewodnik GUM - Wyrażanie niepewności pomiaru (Guide to the expression of uncertainty in measurement). Główny Urzqud Miar, 1999.

[3] EA-4/02 M: 2013. Wyznaczanie niepewności pomiaru przy wzorcowaniu. 2013. 


\section{Conclusions}

This article presents the most important issues related to measurement uncertainty in the context of ensuring the consistency and reliability of measurements. Reliable measurement were characterized and the most important definitions related to measurement uncertainty were included. The goals, methods and stages of the determination and sources of measurement uncertainty were also mentioned. It was emphasized that the Rail Vehicles Research Laboratory operating within the Rail Vehicles Institute TABOR in Poznań ensures the reliability of the measurements performed by complying with the normative requirements, i.e. maintaining the measurement consistency and determining the measurement uncertainty.
[4] EA-04/16. Wytyczne EA dotyczace wyrażania niepewności w badaniach ilościowych. 2003.

[5] DA-06. Polskie Centrum Akredytacji. Polityka dotyczqca zapewnienia spójności pomiarowej. Wydanie 6, 2017.

[6] ILAC-G17:2002. Wprowadzenie problematyki niepewności pomiaru $w$ badaniach $w$ zwiazku z wejściem do stosowania normy ISO/IEC 17025.

[7] International Vocabulary of Basic and General Terms in Metrology (VIM). International Organization for Standardization. 1993.

[8] Izydorczyk J.: Wyznaczenie niepewności pomiarów. PROLAB. Biuro Naukowe Techniczne. 2004.

[9] Vademecum. Polska Administracja Miar. GUM 2015.

[10] VDA 5. Zarzadzanie jakościa w przemyśle samochodowym. Zdatność procesów kontroli. Wydanie 2. 2010

[11] Fraczek J., Makowski R.: Spójność pomiarowa $w$ teorii $i$ praktyce. Pojazdy Szynowe nr 01/2017.

[12] Kogut J.: Niepewności pomiarowe stanowiska badawczego $3 S B$ w Laboratorium Badań Pojazdów Szynowych (praca magisterska). Poznań 2018.

[13] Kostyrko K., Piotrowski J.: Wzorcowanie aparatury pomiarowej. Podstawy teoretyczne i trasabilność wedlug ISO 9000 i zaleceń międzynarodowych. Wydawnictwo Naukowe PWN. Warszawa 2000.

[14] Tarczewski R.: Spójność pomiarowa jeden z determinantów wiarygodności wyników badań. Pojazdy Szynowe $n r$ $02 / 2012$. 